\title{
Analysis on the Trade Comparative Advantage of Manufacturing Industry in Guangzhou to the Belt and Road Area: Based on the RSCA Index
}

\author{
XiaoFei Luo ${ }^{1}$, YongHui Han $^{2 *}$, DongMing Wei ${ }^{3}$ \\ ${ }^{1}$ Faculty of Logistics, Guangdong Mechanical and Electrical Technical College, Guangzhou, Guangdong 510515, China \\ ${ }^{2}$ Guangdong Institute for International Strategies, Guangdong University of Foreign Studies, Guangzhou, Guangdong 510420, China \\ ${ }^{3}$ School of Business, Guangdong University of Foreign Studies, Guangzhou, Guangdong 510006, China
}

\begin{abstract}
After the economic development has entered the new normal stage, the manufacturing industry in Guangzhou faces new challenges and opportunities, and it urgently needs to change the way of its economy development. This paper uses the RSCA index to analyze Guangzhou's problems existing in the manufacturing industry, and to compare the situation to six different areas along the B\&R. The results show that, Guangzhou has a long and steady comparative advantage in the garment and textile sector, metal products and leather products sector while it is comparative disadvantage in metal smelting and processing sector, chemical products sector and non-metallic mineral sector. From the perspective of regional comparison, Guangzhou has the strongest competitiveness with ASEAN and South Asia while it is complimentarily with Central Asia and West Asia.
\end{abstract}

\section{Introduction}

As one of the earliest coastal open cities, Guangzhou has gradually become an export-oriented city and integrated into the global value chain division system led by the developed countrieswith its competitive advantages such as geographical location, business culture, labor and natural resources. Since the 90 s of last century, Guangzhou has set upthe automobile manufacturing, electronics manufacturing and petrochemical manufacturing as the three backbone industries of the city and this structure has not changed so far.

To date, the manufacturing industry in Guangzhou is still lagging behind in the $\mathrm{R} \& \mathrm{D}$, design and marketing strategy. It is in the low-end position in the interest distribution map of the global value chain and gets a small share of interest. The slowdown of both the domestic and abroad economy has great impact on Guangzhou's manufacturing industry. The three traditional backbone industries cannot provide sufficient motivation to the manufacturing industry and its overall growth has slow down. In 2015, Guangzhou's total output value of manufacturing industry was 1.63 trillion
Yuan, an increase of $2 \%$ over the same period of previous year, accounting for $13.8 \%$ of the total output value of the province's manufacturing industry. The added value of manufacturing industry was 0.4 trillion Yuan, an increase of $2.2 \%$ over last year.

Although the scale of manufacturing in Guangzhou is constantly expanding, the growth rate has gradually shifted into the steady growth of low speed (see Figure 1). However, the initiative put forward by the Central Government of China such as 'Belt and Road', 'Going Out Strategy' and 'Made in China 2025' has brought new opportunities to enhancing Guangzhou's manufacturing industry. Facing the opportunities, the first task is to clarify the comparative advantages of manufacturing industriesin Guangzhou to the Belt and Road area.

This paper uses the RSCA index toanalyze the manufacturing industry situation in Guangzhou to the B\&R area.In order to enhance its innovation capacity and its position in the global value chain, Guangzhou's manufacturing industry shall follow the rules of comparative advantages of international production capacity and broaden its cooperation space.

\footnotetext{
*Corresponding author : hanyonghui2006@foxmail.com
} 


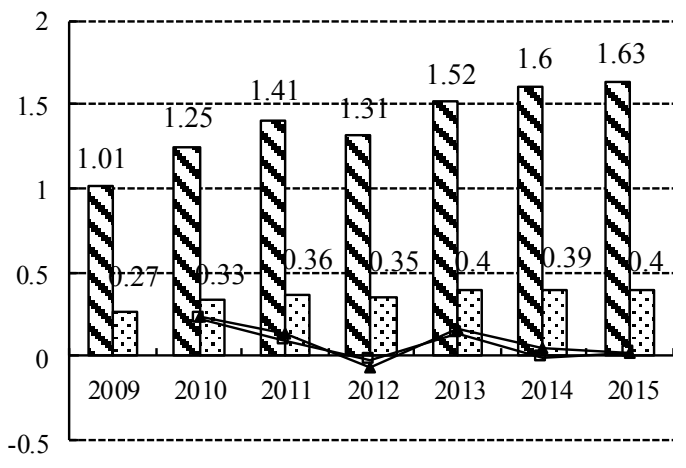

Gross Output Value Added Value

— Increase Rate of Gross Output Value

Fig. 1. Analysis on the development of Guangzhou's manufacturing industry ${ }^{1}$ (Unit: Trillion Yuan)

\section{Methods on comparative advantages analysis}

\subsection{RSCA Index Classified by Sectors}

The RCA index ( Revealed Comparative Advantage Index ) is a commonly used measuring method in the literature of analysis on comparative advantage.It was first proposed by Balassa [1]. The formula is: $R C A_{i t}=\left(X_{i j} / X_{i j}\right) /\left(X_{i w} / X_{t w}\right)$, where $X_{i j}$ is the export of product $i$ from area $\mathrm{j}, X_{i j}$ is the total export from area $\mathrm{j}$, $X_{i v}$ is the world's export of product i and $X_{w w}$ is world's total export.

The RCA index can measure the comparative advantage level of different trade sectors in an area. When RCA index of a specific trade sector is above 1, it indicates that the sector in this area has comparative advantage, otherwise it has comparative disadvantage. However, Benedictis[2] found in his further research that, the RCA index has the defect of asymmetric on measuring comparative advantage. When the index value is between $0-1$, it is considered as of comparative disadvantage, while the value range is $[1,+\infty]$, it is considered as of comparative advantage. The judgment value ofthe two rangesis not symmetrical, which makes the measured indicators distribution skew and directly affects the intuitive judgment on the comparative advantages of various industrial sectors.

In view of this, this paper uses the RSCA index to correct the RCA index deviation [3]. The formula is: $R S C A=(R C A-1) /(R C A+1)$.By modifying the asymmetry bias of the RCA index, the RSCA index can be narrowed down the value range to $[-1,1]$. If the value of RSCA index is $[0,1]$, it indicates that the industrial sector has comparative advantage, while the value of $[-1$, $0]$ has comparative disadvantage.

\footnotetext{
${ }^{1}$ Data collected from Guangzhou statistical information network: http://www.gzstats.gov.cn/
}

The variables used in this paper are from 1995 to 2014. The data are from the World Trade Database, the UN Trade Database, the World Bank Database and the Guangzhou Statistical Yearbook.

According to China's industry classification for national economic activities(GB-T4753-2011), the related manufacturing industry is divided into 11 sectors: food processing, wood products, non-metallic mineral, metal smelting and processing, chemical products, leather products, paper and printing, garment and textile, metal products, sports and entertainment and equipment manufacturing.The calculation results of RSCA index of the above manufacturing industry sectors are shown in Table 1.

Table 1. Results of RSCA index of Guangzhou manufacturing industryclassified by sectors (1995-20174)

\begin{tabular}{|c|c|c|c|c|c|c|c|}
\hline & $\begin{array}{c}\text { Food } \\
\text { process- } \\
\text { ing }\end{array}$ & $\begin{array}{l}\text { Wood } \\
\text { pro- } \\
\text { ducts }\end{array}$ & \multicolumn{2}{|c|}{$\begin{array}{l}\text { Metal } \\
\text { smelting } \\
\text { and } \\
\text { process- } \\
\text { ing }\end{array}$} & $\begin{array}{c}\text { Chemi- } \\
\text { cal pro- } \\
\text { ducts }\end{array}$ & $\begin{array}{c}\text { Non- } \\
\text { metallic } \\
\text { mineral }\end{array}$ & $\begin{array}{c}\text { Metal } \\
\text { products }\end{array}$ \\
\hline 1995 & \begin{tabular}{l|l}
0.373 & -
\end{tabular} & -0.663 & \multicolumn{2}{|c|}{-0.983} & -0.044 & \begin{tabular}{l|l|}
-0.599 \\
\end{tabular} & 0.630 \\
\hline 1996 & $0.326-$ & -0.689 & \multicolumn{2}{|c|}{-0.985} & -0.602 & -0.584 & 0.580 \\
\hline 1997 & \begin{tabular}{l|l}
0.280 & -
\end{tabular} & -0.687 & \multicolumn{2}{|c|}{-0.988} & -0.504 & -0.568 & 0.679 \\
\hline 1998 & \begin{tabular}{l|l}
0.233 & - \\
\end{tabular} & -0.548 & \multicolumn{2}{|c|}{-0.990} & -0.406 & \begin{tabular}{|l|l|} 
& -0.552 \\
\end{tabular} & 0.688 \\
\hline 1999 & \begin{tabular}{l|l}
0.186 & - \\
\end{tabular} & -0.409 & \multicolumn{2}{|c|}{-0.993} & -0.309 & -0.536 & 0.737 \\
\hline 2000 & \begin{tabular}{l|l}
0.139 & -
\end{tabular} & -0.269 & \multicolumn{2}{|c|}{-0.995} & -0.211 & -0.520 & 0.606 \\
\hline 2001 & $0.038-$ & -0.234 & \multicolumn{2}{|c|}{-0.993} & -0.165 & -0.346 & 0.815 \\
\hline 2002 & \begin{tabular}{l|l}
-0.102 & -
\end{tabular} & -0.144 & \multicolumn{2}{|c|}{-0.994} & -0.328 & \begin{tabular}{|l|l|} 
& -0.218 \\
\end{tabular} & 0.574 \\
\hline 2003 & -0.008 & -0.352 & \multicolumn{2}{|c|}{-0.995} & -0.423 & \begin{tabular}{l|l|}
-0.386 \\
\end{tabular} & 0.229 \\
\hline 2004 & $-0.077 \quad-$ & -0.426 & \multicolumn{2}{|c|}{-0.995} & -0.299 & \begin{tabular}{|l|l|}
-0.496 \\
\end{tabular} & 0.506 \\
\hline 2005 & $-0.206-$ & -0.296 & \multicolumn{2}{|c|}{-0.998} & -0.444 & -0.607 & 0.497 \\
\hline 2006 & $-0.237-$ & -0.108 & \multicolumn{2}{|c|}{-0.997} & -0.372 & -0.654 & 0.651 \\
\hline 2007 & -0.370 & -0.343 & \multicolumn{2}{|c|}{-0.997} & -0.291 & -0.631 & 0.268 \\
\hline 2008 & $-0.456-$ & -0.840 & \multicolumn{2}{|c|}{-0.990} & -0.403 & -0.702 & 0.227 \\
\hline 2009 & $-0.626-$ & -0.460 & \multicolumn{2}{|c|}{-0.987} & -0.519 & -0.666 & 0.863 \\
\hline 2010 & $-0.726-$ & -0.736 & \multicolumn{2}{|c|}{-0.983} & -0.505 & \begin{tabular}{|l|l|} 
& -0.811 \\
\end{tabular} & 0.738 \\
\hline 2011 & $-0.761 \mid-$ & -0.711 & \multicolumn{2}{|c|}{-0.990} & -0.439 & \begin{tabular}{l|l}
-0.818 \\
\end{tabular} & 0.651 \\
\hline 2012 & \begin{tabular}{l|l}
-0.781 & -
\end{tabular} & -0.329 & \multicolumn{2}{|c|}{-0.988} & -0.521 & -0.746 & 0.280 \\
\hline 2013 & $-0.818-$ & -0.817 & \multicolumn{2}{|c|}{-0.986} & -0.572 & \begin{tabular}{|l|l|} 
& -0.619 \\
\end{tabular} & 0.825 \\
\hline \multirow[t]{2}{*}{2014} & \begin{tabular}{l|l}
-0.816 & -
\end{tabular} & -0.830 & -0.9 & 88 & -0.562 & \begin{tabular}{|l|}
-0.202 \\
\end{tabular} & 0.792 \\
\hline & $\begin{array}{c}\text { Equip- } \\
\text { ment } \\
\text { manu- } \\
\text { facturing }\end{array}$ & \multicolumn{2}{|c|}{\begin{tabular}{|c|c|}
$\begin{array}{c}\text { Leather } \\
\text { products }\end{array}$ & a \\
\end{tabular}} & \multicolumn{2}{|c|}{$\begin{array}{c}\text { Garment } \\
\text { and textile }\end{array}$} & $\begin{array}{c}\text { Paper and } \\
\text { printing }\end{array}$ & $\begin{array}{l}\text { Sports and } \\
\text { entertain- } \\
\text { ment }\end{array}$ \\
\hline 1995 & -0.782 & \multicolumn{2}{|c|}{0.501} & & 537 & -0.844 & 0.501 \\
\hline 1996 & -0.556 & 0.4 & & & 234 & -0.868 & 0.645 \\
\hline 1997 & -0.809 & 0.5 & & & 686 & -0.878 & 0.479 \\
\hline 1998 & -0.681 & 0.7 & & & 371 & -0.881 & 0.778 \\
\hline 1999 & -0.549 & 0.8 & & & 674 & -0.862 & 0.671 \\
\hline 2000 & -0.417 & 0.9 & & & 976 & -0.842 & 0.632 \\
\hline 2001 & -0.364 & 0.8 & & & 565 & -0.813 & 0.440 \\
\hline 2002 & -0.157 & 0.6 & & & 742 & -0.793 & 0.800 \\
\hline 2003 & 0.290 & -0.3 & & & 378 & -0.724 & 0.719 \\
\hline 2004 & 0.543 & -0.1 & & & 594 & -0.601 & 0.597 \\
\hline 2005 & 0.710 & -0.2 & & & 321 & -0.545 & 0.507 \\
\hline 2006 & 0.777 & -0.0 & & & 603 & -0.432 & 0.328 \\
\hline 2007 & 0.864 & -0.6 & & & 486 & -0.333 & 0.662 \\
\hline 2008 & 0.807 & 0.0 & & & 672 & -0.133 & 0.140 \\
\hline 2009 & 0.666 & 0.1 & & & 734 & -0.239 & -0.266 \\
\hline 2010 & 0.644 & -0.3 & & & 735 & -0.556 & -0.256 \\
\hline 2011 & 0.551 & -0.8 & 320 & & 939 & -0.547 & -0.645 \\
\hline 2012 & 0.717 & -0.2 & & & 799 & -0.591 & -0.489 \\
\hline
\end{tabular}




\begin{tabular}{|l|l|l|l|l|l|}
\hline 2013 & 0.875 & 0.607 & 0.354 & -0.535 & -0.186 \\
\hline 2014 & 0.756 & 0.546 & 0.398 & -0.529 & -0.420 \\
\hline
\end{tabular}

From Table 1 we see: First of all, fromthe changesof index of Guangzhou's manufacturing industries divided by industrial sectors, the comparative advantage indexarepositivein garment and textile sector and metal products sector, while they are negative on metal smelting processing sector, chemical processingand manufacturing sector, non-metallic mineral products sector and paper and printing sector.Thatmeans that Guangzhou has a long and steady comparative advantage in the labor-intensive industries such as garment and textile and metal products. However, Guangzhou shows a long-term disadvantage in manufacturing industries such as metal smelting processing, chemical processing and manufacturing,non-metallic mineral products.

Secondly, the average RSCA index value of Guangzhou's metal smelting sector is -0.9 (even in some years the index value is -0.998 ) and the average RSCA index value of the paper printing sector, wood processing sector and non-metallic mineral products sectorare around -0.7 . These important manufacturing sectors are at a relatively significant disadvantage.

Thirdly, from the time trend of RSCA index, the RSCA index of Guangzhou's equipment manufacturing sectorraised from the -0.782 to 0.756 , which shows that over the past 20 years, the equipment manufacturing sector with high technology contentin Guangzhouhas beengrowing strongly and theeffect of industrial transformation and upgrading is obvious.

\subsection{Comparative Analysis to theB\&R Area}

In order to provide a clearer analysis of the comparative advantages of manufacturing industries in Guangzhou to the 65 countries along theBelt and Road area ${ }^{2}$, we need to conduct a horizontal comparative analysis. We make $X_{i w}$ and $X_{t w}$ in the formula $R C A_{i t}=\left(X_{i j} / X_{i j}\right) /\left(X_{i w} / X_{t w}\right)$ representing the $\mathrm{B} \& \mathrm{R}$ area and we will see the comparative advantage in Guangzhou to B\&R area. The Table 2 shows the RSCA index of manufacturing industries in Guangzhou to B\&R area from 1995 to 2014.

\footnotetext{
${ }^{2}$ According to the national data along the Belt and Road Network of China (https://www.yidaiyilu.gov.cn), 65 countries were selected as the research samples, including India, Ethiopia, Bosnia and Herzegovina, Montenegro, Turkmenistan, Lithuania, Latvia, Palestine, Albania Afghanistan, Estonia, Pakistan, Slovenia, Croatia, Lebanon, Oman, Bahrain, Yemen, Egypt, Jordan, Syria, Indonesia, Philippines, Singapore, Israel, Azerbaijan, Armenia, Czech Republic, Bangladesh, Belarus, Cambodia, Georgia Myanmar, Brunei, East Timor, Bhutan, United Arab Emirates, Thailand, Vietnam, Hungary, Iraq, Iran, Kyrgyzstan, Laos, Kazakhstan, Qatar, Kuwait, Moldova, Maldives, Malaysia, Macedonia, Mongolia, Nepal, Poland, Bulgaria, Romania, Serbia, Saudi Arabia, Slovakia, Tajikistan, Russia, South Africa, Sri Lanka, Turkey, Ukraine and Uzbekistan.
}

Table 2. RSCA index of manufacturing industries in Guangzhou to B\&R area(1995-2014)

\begin{tabular}{|c|c|c|c|c|c|c|c|}
\hline & $\begin{array}{c}\text { Food } \\
\text { process- } \\
\text { ing }\end{array}$ & $\begin{array}{l}\text { Wood } \\
\text { pro- } \\
\text { ducts }\end{array}$ & \multicolumn{2}{|c|}{\begin{tabular}{|c|} 
Metal \\
smelting \\
and \\
process- \\
ing \\
\end{tabular}} & $\begin{array}{l}\text { Chemi- } \\
\text { cal pro- } \\
\text { ducts }\end{array}$ & $-\begin{array}{c}\text { Non- } \\
\text { metallic } \\
\text { mineral }\end{array}$ & $\begin{array}{c}\text { Metal } \\
\text { products }\end{array}$ \\
\hline 1995 & -0.136 & 0.626 & \multicolumn{2}{|c|}{-0.989} & -0.911 & -0.890 & -0.556 \\
\hline 1996 & -0.221 & 0.455 & \multicolumn{2}{|c|}{-0.990} & -0.827 & -0.879 & -0.785 \\
\hline 1997 & -0.461 & 0.194 & \multicolumn{2}{|c|}{-0.991} & -0.744 & -0.869 & -0.513 \\
\hline 1998 & -0.701 & 0.333 & \multicolumn{2}{|c|}{-0.991} & -0.660 & -0.859 & -0.242 \\
\hline 1999 & -0.556 & 0.672 & \multicolumn{2}{|c|}{-0.992} & -0.577 & -0.848 & -0.390 \\
\hline 2000 & -0.411 & 0.411 & \multicolumn{2}{|c|}{-0.993} & -0.493 & -0.838 & -0.537 \\
\hline 2001 & -0.739 & 0.474 & \multicolumn{2}{|c|}{-0.990} & -0.449 & -0.747 & 0.157 \\
\hline 2002 & -0.632 & 0.276 & \multicolumn{2}{|c|}{-0.989} & -0.542 & -0.713 & 0.503 \\
\hline 2003 & 0.095 & 0.401 & \multicolumn{2}{|c|}{-0.988} & -0.583 & -0.791 & 0.519 \\
\hline 2004 & 0.379 & -0.736 & \multicolumn{2}{|c|}{-0.990} & -0.527 & -0.827 & 0.523 \\
\hline 2005 & 0.468 & -0.886 & \multicolumn{2}{|c|}{-0.995} & -0.599 & -0.872 & 0.238 \\
\hline 2006 & 0.309 & -0.941 & \multicolumn{2}{|c|}{-0.991} & -0.517 & -0.866 & 0.147 \\
\hline 2007 & 0.652 & -0.160 & \multicolumn{2}{|c|}{-0.994} & -0.424 & -0.804 & 0.012 \\
\hline 2008 & -0.674 & 0.329 & \multicolumn{2}{|c|}{-0.965} & -0.645 & -0.893 & 0.104 \\
\hline 2009 & 0.225 & -0.326 & \multicolumn{2}{|c|}{-0.955} & -0.612 & -0.864 & 0.118 \\
\hline 2010 & 0.239 & -0.579 & \multicolumn{2}{|c|}{-0.957} & -0.629 & -0.873 & 0.256 \\
\hline 2011 & 0.371 & -0.624 & \multicolumn{2}{|c|}{-0.959} & -0.653 & -0.874 & 0.491 \\
\hline 2012 & 0.318 & -0.292 & \multicolumn{2}{|c|}{-0.950} & -0.689 & -0.873 & 0.388 \\
\hline 2013 & 0.239 & -0.691 & \multicolumn{2}{|c|}{-0.950} & -0.700 & -0.836 & 0.197 \\
\hline \multirow[t]{2}{*}{2014} & 0.432 & -0.725 & \multicolumn{2}{|c|}{-0.969} & -0.728 & -0.714 & 0.298 \\
\hline & $\begin{array}{l}\text { Equip- } \\
\text { ment } \\
\text { manu- } \\
\text { facturing }\end{array}$ & \multicolumn{2}{|c|}{$\begin{array}{c}\text { Leather } \\
\text { products }\end{array}$} & \multicolumn{2}{|c|}{$\begin{array}{c}\text { Garment } \\
\text { and textile }\end{array}$} & $\begin{array}{l}\text { aper and } \\
\text { printing }\end{array}$ & $\begin{array}{l}\text { Sports and } \\
\text { entertain- } \\
\text { ment }\end{array}$ \\
\hline 1995 & -0.613 & 0.2 & & & 357 & 0.336 & 0.613 \\
\hline 1996 & -0.586 & 0.3 & & & 223 & 0.091 & 0.571 \\
\hline 1997 & -0.559 & 0.3 & & & 395 & -0.155 & 0.813 \\
\hline 1998 & -0.653 & 0.4 & & & 286 & -0.400 & 0.591 \\
\hline 1999 & -0.551 & 0.4 & & & 417 & -0.646 & 0.101 \\
\hline 2000 & -0.448 & 0.5 & & & 549 & -0.891 & -0.389 \\
\hline 2001 & -0.496 & 0.5 & & & 642 & -0.417 & -0.196 \\
\hline 2002 & -0.432 & 0.3 & & & 690 & -0.357 & 0.724 \\
\hline 2003 & -0.151 & 0.0 & & & 042 & 0.419 & 0.151 \\
\hline 2004 & -0.024 & 0.0 & & & 216 & -0.336 & -0.319 \\
\hline 2005 & 0.046 & 0.0 & & & 439 & 0.459 & 0.024 \\
\hline 2006 & 0.025 & 0.6 & & & .010 & -0.377 & -0.720 \\
\hline 2007 & 0.030 & 0.7 & & & 017 & -0.299 & 0.676 \\
\hline 2008 & 0.293 & 0.7 & & & 014 & -0.426 & 0.350 \\
\hline 2009 & 0.291 & 0.6 & & & 586 & -0.030 & 0.322 \\
\hline 2010 & 0.423 & 0.6 & & & 541 & -0.711 & 0.080 \\
\hline 2011 & 0.418 & 0.6 & & & 577 & -0.957 & 0.466 \\
\hline 2012 & 0.519 & 0.7 & & & 473 & -0.868 & -0.099 \\
\hline 2013 & 0.460 & 0.8 & 43 & & 434 & -0.057 & 0.013 \\
\hline 2014 & 0.449 & 0.7 & & & 821 & -0.222 & -0.302 \\
\hline
\end{tabular}

As shown in Table 2, from view of the change of manufacturing RSCA index of Guangzhou to the B\&R area, the resultsare positive in garment and textile sector, metal products sector, leather productssector and sports and entertainment sector for most of the time, which reveals a long-standing comparative advantage, while they are negative in metal smelting and processing sector, chemical products sector and non-metal mineral products sector, which shows a long-standing comparative disadvantage. From the view of value of the RSCA index, the value of Guangzhou's metal smelting index wanders around -0.97 and the index value of non-metallic mineral products is around -0.84 , which indicates that these 
important manufacturing sectors are of a significant comparative disadvantage. From the view of trend of the index, the index of equipment manufacturing sector rose from -0.613 of comparative disadvantage to 0.449 of comparative advantage. The index of food processing sector also fluctuated from a comparative disadvantage point to a comparative advantage point. This comprehensively explains that the transformation effect is significant in the equipment manufacturing sector and food processing sector in Guangzhou in recent years.

We group the 65 countries alongthe B\&R area into six major regions as ASEAN, West Asia (WA), Central Asia (CA), South Asia (SA), the Commonwealth of Independent States (CIS), Central and Eastern Europe (CEE)(see Figure 2).

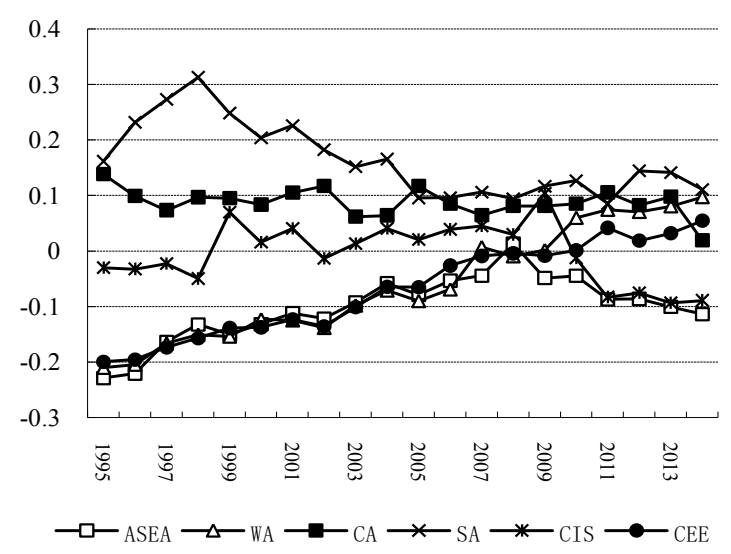

Figure 2 Comparative Advantages of Manufacturing Industries in Guangzhou to the Six Groups of B\&R Area

The Figure 2 shows change trend of the comparative advantage of Manufacturing Industries in Guangzhou to the Six Groups ofB\&R Area. From 1995 to 2014, Guangzhou's manufacturing industry has maintained its comparative advantage to South Asia (SA) and Central Asian (CA). However, there have been signs of declining in recent years, especially to South Asian. Since 1998, a significant downward trend has appeared. Although Guangzhou's manufacturing industry has more advantages in technology and high technological development than South Asia and Central Asia which makes Guangzhou maintaining a comparative advantage for a long time, as the cost of labor increases and the demographic dividends disappeared in Guangzhou, labor cost advantage in South Asia and Central Asia gradually appears [4], and the comparative advantage of Guangzhou's manufacturing industry is becoming weakened.

From 1995 to 2008, Guangzhou has been at a disadvantage position to ASEAN, West Asia (WA) and Central and Eastern Europe (CEE), but the disadvantage was constantly diminishing. The main reason may be that economic development of West Asia and Central and Eastern Europe and manufacturing exports were severely affected were the global financial crisis.
To ASEAN, Guangzhou's manufacturing industry turned from a comparative disadvantage to a comparative advantage in 2008 , but turned into a comparative disadvantage in 2009 and continued to expand.After the global financial crisis in 2008, the domestic economic growth slowed down and the demand in the international market was sluggish. All these unfavorable factors weakened the international competitiveness of Guangzhou's manufacturing industry. Guangzhou and ASEAN countries have generally similar manufacturing structures, but ASEAN countries have lower labor costs [5], which enlarges the comparative disadvantage of manufacturing in Guangzhou to ASEAN.

In recent years, Guangzhou's manufacturing industry is under double pressure: the internal labor costs and operating costs continue to rise and theexternal economic conditions have continued to slump. In such situation, the trade condition is deteriorating. The lowend manufacturing industries have been hit by low-cost impacts from the Southeast Asia countries; while in the domestic market, the high-end manufacturing industries were suffered from the competitiveness from developed countries.

As a result, Guangzhou's manufacturing industry has begun to enter a new normal situation under the dual pressures from inside and outside.

\section{Conclusion and suggestion}

Guangzhou needs to develop the science and technology industries and promote the relevant policies on improving the development of modern manufacturing industry to promote the relevant policies as follows:

First of all, Guangzhou should make reasonable preparation of its advanced manufacturing industry development plan to promote technological innovation in industrial enterprises. Take advantages of the opportunities of Industry 4.0 era and 'Made in China $2025^{\prime}$ strategy to deepen the innovation of industry and information transformation.

Secondly, Guangzhou shouldformulatethe high-end manufacturing development plans to strengthen the support of emerging industries. In order to support the breakthroughs of core manufacturing technology and its carrier construction and to cultivate the backbone enterprises, Guangzhou should increase the proportion of R\&D expenditures in the city. Guangzhoucanmake full use of the capital resources like integrating the existing government funds, introducing the social capital, establishing the industry development funds or even establish the investment funds with Guangdong Province to attract more innovative investment enterprises.

Thirdly, a combination of policiesshould be introduced to promote manufacturing enterprises to reduce the cost of production factors and the business burden.

Finally, the government should give full play to its role as a platform for foreign exchange and cooperation such as the Guangzhou Overseas Exchange Association to guide the resources of overseas Chinese businessmen and overseas Chinese experts and scholars to flow into 
Guangzhou and helpthe advanced manufacturing projects, personnel and funds to settle down in Guangzhou.

\section{Acknowledgements}

This work is partially supported by Key Grant Projects of Philosophy and Social Sciences Research, Ministry of Education of China (Grant No.16JZD018). Yonghui Han is the corresponding author, the e-mail is hanyonghui2006@foxmail.com.

\section{References}

1. B. Balassa, Trade Liberalisation and "Revealed" Comparative Advantage. Manchester School, 33(2):99-123(1965).

2. L D.Benedictis, Three Decades of Italian Comparative Advantages. World Economy, 28(11):1679-1709(2005).

3. T. Shang, Empirical Study on Comparative Advantage and Trade Pattern Change of Trade in Services of China: Analysis Based on RSCA and Lafay Indices. Journal of International Trade, 12:70-77(2010).

4. Y. H. Han, X. F. Luo, Study on Regional Trade cogoverance between China and Central Asia: Feasibility of Establishing FTA Based on the "Belt and Road" Initiative. International Economics and Trade Research, 33(02):72-84(2017).

5. S. H.Wang, X. J. Yuan, Analysis of the Locational Selection of theIndustiresDerectly Invested by Guangdong Enterprises in ASEAN. International Economics and Trade Research, 27(10):4652(2011). 